\title{
Five-year field performance of two types of Douglas fir mini-plug transplants in three forest sites in France
}

\author{
Benoît Généré \\ Cemagref, Forest planting stock and genetic resources division, domaine des Barres, \\ 45290 Nogent-sur-Vernisson, France
}

(Received 21 October 1997; accepted 18 February 1998)

\begin{abstract}
To assess the respective abilities of two plant types of Douglas fir mini-plug transplants (MPT), namely MP +1 and MP + 2, three field trials were established by Cemagref in 1991 on sites with very different soil fertility levels. The MPT had been grown at two different nursery sites, and therefore, were compared to standard seedlings from the same nursery, which were 1 year older. Their field performance was followed from planting to age 5 , when a complete assessment was made. The results depended on both stock type and planting site. MP +2 stock showed promise, especially on medium and low-fertility soils, where the cumulative 5-year height growth was increased by 60 and $80 \%$, respectively. In contrast, MP +1 stock performed less well than its control on all sites, and especially on low-fertility soils where the cumulative 5 -year height growth was $50 \%$ less. Moreover, on the medium-fertility soil, severe wind-throw occurred at age 4 because of increased root deformities. The performance levels of both controls, grown in different nursery sites in 2 or 3 years, were actually rather similar, irrespective of planting site and seed source. (@ Inra/Elsevier, Paris.)
\end{abstract}

mini-plug transplants / stock type / Pseudotsuga menziesii / plantation / soil fertility

Résumé - Performances de deux types de plants repiqués de Douglas issus de semis en « miniplugs $», 5$ ans après plantation sur trois sites forestiers. Pour évaluer l'intérêt de deux types de plants de Douglas semés en «mini-plugs » puis repiqués $(\mathrm{MP}+1$ et $\mathrm{MP}+2)$, trois essais en plantation ont été installés en 1991 dans des stations à fertilité variable. Ces deux types de plants ont été produits sur des pépinières différentes, avec un témoin local pour chacun. Cinq ans après plantation, les résultats dépendaient du type de plant et du site de plantation. MP +2 a été performant, surtout sur les sols à fertilité moyenne et faible où la croissance cumulée sur 5 ans a été accrue de 60 et $80 \%$, respectivement. Inversement, $\mathrm{MP}+1$ a présenté une performance amoindrie, particulièrement sur le sol peu fertile où sa croissance totale a été réduite de $50 \%$. De plus, ses déformations racinaires ont réduit sa résistance au vent. Enfin, les performances des deux témoins ont été proches, quel que soit le site de plantation.

mini-plug / type de plant / Pseudotsuga menziesii / plantation / fertilité du sol

\footnotetext{
* Correspondence and reprints

E-mail: benoit.genere@cemagref.fr
} 


\section{INTRODUCTION}

Classic plug transplants, especially plug $+1 \mathrm{~s}$, have been in use in the United States since 1971 [7] as a way to accelerate nursery production and increase root system fibrosity of bareroot seedlings. Traditionally, plug +1 seedlings are grown in a greenhouse for 1 year, then transplanted and grown in a bareroot nursery for an additional year $[7$, 141 .

Since 1983, a more sophisticated technique of producing planting stock called 'mini-plug transplant (MPT)' has been adapted from the agricultural transplant industry and developed by Weyerhaeuser Company [8]. It first focused on Douglas fir seedlings, but was quickly extended to rooted cuttings [12] and other species [11, 16]. The MPT production cycle includes two parts: 1) an early sowing or rooting phase in very small-cavity trays under a controlled greenhouse environment, which generally extends from January to May. This is followed by 2) a transplanting phase in nursery beds, which ends when the planting stock meets the required morphological standards. Thus, production time is often reduced by as much as a year, though this varies with species and nursery locations.

Plug and mini-plug transplants are also known in regions other than the United States, especially in Canada [1], in South America [6] and in Europe. Here, MPT stocks were available from 1988 to 1991 , with the establishment in the Netherlands of the European branch of Arborgen, a subsidiary of Weyerhaeuser Company.

During this period of time, the mini-plug starter crops were transplanted in different forest nurseries across Europe, mainly for commercial purposes. In collaboration with Arborgen-Europe, Cemagref was involved, first, in testing the quality of different stocks of MPT produced in a French State Forest nursery at Peyrat-le-Château [3], and, second, in establishing three field trials with two MPT plant types in Douglas fir. The aim of these experimental plantations was to determine whether two MPT stocks, namely the classic MP +1 stock (produced within a year) and the less common MP +2 stock (produced in 2 years), each grown in an appropriate nursery, could be recommended for reforestation purposes, in terms of survival and early growth potential, as compared to the standard stock produced in each nursery, and which was 1 year older in both locations $(1+1$ and $2+1$ stocks, respectively).

The two tested MPT stocks are usually sown in mini-plugs (MP) and grown until May in a greenhouse, then transplanted $(t)$ and grown in a bareroot nursery for one growing season (MP +1 stock) or two additional seasons ( $\mathrm{MP}+2$ stock).

This article reports the results of these field trials obtained 5 years after planting. Some early field results from other experiments with MPT seedlings [15] or classic plug transplants $[1,9]$ are available and generally show positive or neutral effects compared to bareroot or plug controls.

\section{MATERIALS AND METHODS}

The three ficld trials were established in different regions of France in 1991, at Châteldon (Auvergne), Saint-Agnant-près-Crocq (Limousin) and Varenguebec (Normandy region). The planted Douglas fir seedlings had been grown at two nursery sites: Préchac (Aquitaine), for MP +1 and $1+1$ stocks, and Peyrat-le-Château (Limousin) for MP +2 and $2+1$ stocks (figure l).

\subsection{Field trials}

\subsubsection{Experimental design}

Each experiment was a randomized complete block design with four treatments (MP $+1,1+1$, $\mathrm{MP}+2,2+1$ stocks), four replicates and 40 seedlings (eight rows by five lines) per experiment unit. At least two border lines were planted around each trial in order to avoid side effects. 


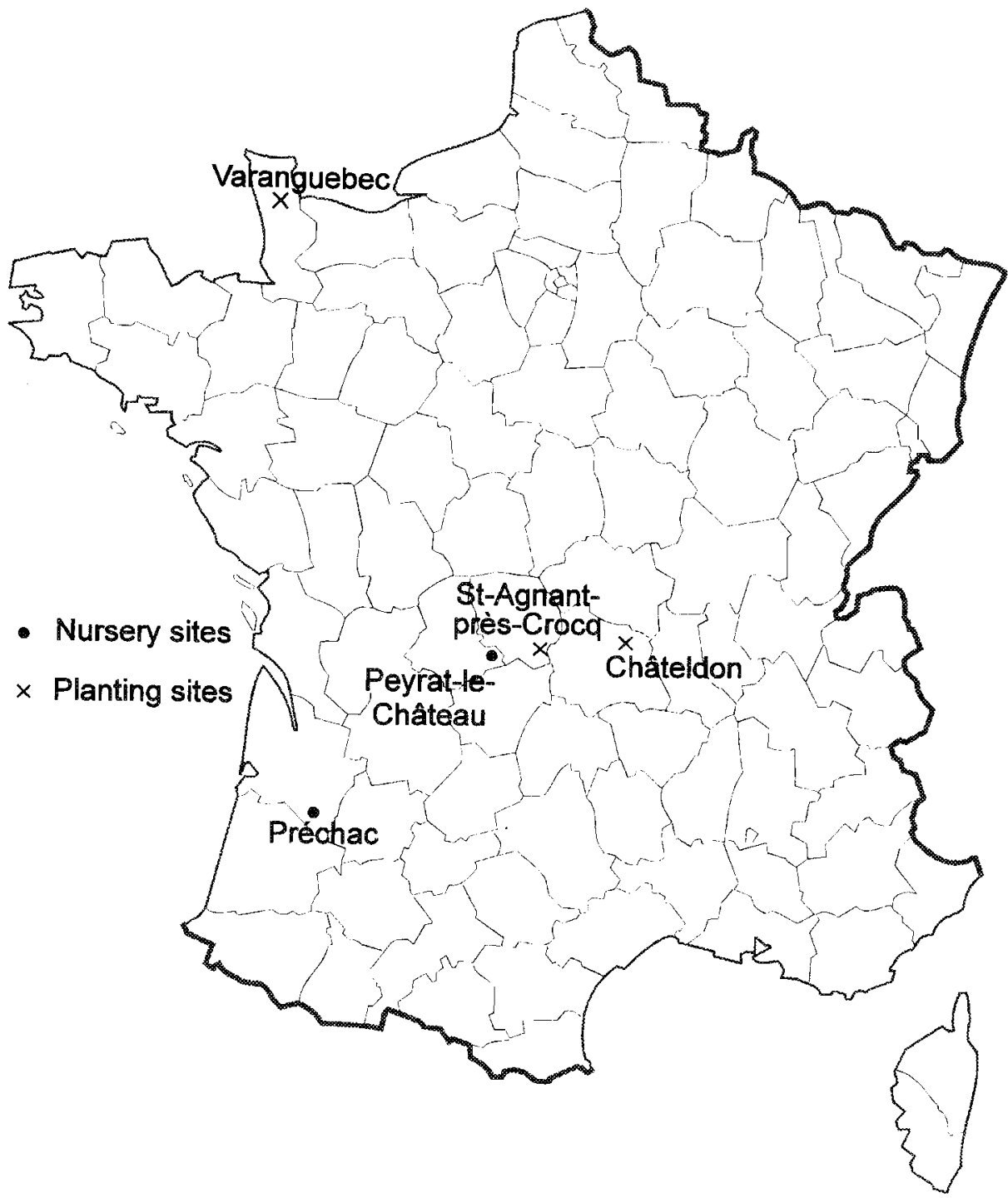

Figure 1. Location of the two nurseries and three forest sites in France.

\subsubsection{Planting site main features}

The planting site at Châteldon is located at the northwestern edge of the 'Livradois-Forez' mountains (lat. 45'57.3' $\mathrm{N}$, long. $3^{\circ} 32^{\prime} \mathrm{E}$, clev. $490-520 \mathrm{~m}$ ), on a steep northerly slope ( $30 \%$ ). The climate is intermediate with occanic, continental and mountain influences; the annual rain- fall is $800 \mathrm{~mm}$ and the mean temperature is $9.5^{\circ} \mathrm{C}$. The soil, classified as 'acid brown', is quite deep (100-120 cm), and developed from a quartzo-feldspathic clayey sand (Oligocene alluvium). Its $30-\mathrm{cm}$-deep upper soil texture is classified as a loamy sand, with $69 \%$ sand and $21 \%$ silt [10]. The humus form is a mull-moder. Vegetation consists mainly of bramble (Rubus 
fruticosus), broom (Cytisus scoparius) and wood poa (Poa nomeralis).

The planting site at St-Agnant-près-Crocq is located on the Millevaches plateau (lat. $45^{\circ} 46.7^{\prime} \mathrm{N}$, long. $2^{\circ} 20.1^{\prime} \mathrm{E}$, elev. $780 \mathrm{~m}$ ), on a slightly southerly slope $(7 \%)$. The climate is classified as similar to Châteldon's, although colder and wetter; the annual rainfall is $1070 \mathrm{~mm}$ and the mean temperature is $7.5^{\circ} \mathrm{C}$. The soil is $80-100 \mathrm{~cm}$ deep, over granite with biotite. Its upper soil texture is a loamy sand, with $66 \%$ sand and $21 \%$ silt. The humus form is an acid mull. The vegetation consists mainly of heather (Calluna vulgaris) and broom (Cytisus scoparius).

The planting site at Varanguebec is located on the Cotentin peninsula (lat. $49^{\circ} 20.8^{\prime} \mathrm{N}$, long. $1^{\circ} 28^{\prime} \mathrm{W}$, elev. $30 \mathrm{~m}$ ), on flat ground inside a private wood (Bois de Limors). The climate is typically oceanic; the annual rainfall is $890 \mathrm{~mm}$ and the mean temperature is $10.3^{\circ} \mathrm{C}$. The soil is very deep (>120 cm), and being excessively damp, it has been drained. It is classified as leached acid brown and was formed over an ancient sandstone bedrock (Siegenien period); its upper-soil texture is a clayey loam (63\% silt, $22 \%$ clay). The humus form is a moder. The ground cover consists mainly of bracken (Pteridium aquilinum), bramble (Rubus fruticosus), sheep sorrel (Rumex acetosella) and honeysuckle (Lonicera periclymenum).

Chemical soil analyses from the upper $30 \mathrm{~cm}$ of all three sites were performed in spring 1994. Results are displayed in table $I$.

All the planting soils are suitable for Douglas fir, with an acid $\mathrm{pH}$, sufficient content in organic matter, and an acceptably high cation exchange capacity. The poorest soil, at St-Agnant, is nearly devoid of exchangeable cations. Its cation saturation rate, which could be a limiting factor on Douglas fir growth [5], is only $4 \%$, versus $10 \%$ at Varanguebec and $26 \%$ at Châteldon. Moreover, a lack of phosphorus appears on all sites, and is more acute at Varanguebec. Lastly, the copper content seems low at Châteldon and StAgnant, but probably is slightly above the critical threshold because very few stems were curved in an S-shape, 5 years after planting [2].

The site index of these planting sites (i.e. dominant tree height at 50 years) is unknown, but target values ranging from 27 to $36 \mathrm{~m}$ are usual for Douglas fir in France [4].

\subsection{Douglas fir seedlings}

\subsubsection{Seed origin}

Seeds from two sources were used depending on nursery and forest sites. The provenance 'Est Massif Central (EMC)' was used at Châteldon and St-Agnant, for all treatments, and at Varanguebec, for the plants grown at Préchac. The provenance 'Nord-Est' was used at Varanguebec, for the seedlings produced at Peyrat-le-Château. Given the location of the plantations, these provenances are recommended by the forest authorities, except EMC at Varenguebec. In the latter case, 'NordEst' provenance was not available at the Préchac nursery, and it was replaced by the provenance tested in the two other sites.

\subsubsection{Nursery sites and growing conditions}

MPT and controls were grown in two nurseries: a State nursery at Peyrat-le-Château (lat. $45^{\circ} 47.1^{\prime} \mathrm{N}$, long. $1^{\circ} 45.2^{\prime} \mathrm{E}$, elev. $570 \mathrm{~m}$ ) and a private nursery, owned by Naudet Company, at Préchac (lat. $44^{\circ} 23.5^{\prime} \mathrm{N}$, long. $0^{\circ} 20.5^{\prime} \mathrm{W}$, elev. $60 \mathrm{~m}$ ). At Peyrat-le-Château, the mean temperature is $9.5^{\circ} \mathrm{C}$ and the annual precipitation is $1300 \mathrm{~mm}$. At Préchac, the mean temperature is $13{ }^{\circ} \mathrm{C}$ and the $900 \mathrm{~mm}$ annual precipitation is complemented by sprinkler irrigation. In both nurseries, the soils are sandy and slightly acid. Seedling growth is better at Préchac because of a more favourable climate and intensive cultural practices, so the common growing cycle duration is reduced by a year on that site. On each nursery site, the MPT stocks were cultivated in a similar way to the other stock types.

Mini-plug starter plants were produced in a heated glasshouse at Alsmeer (the Netherlands) from early February to May, in 1989 and in 1990. They were transplanted by hand (using a dibble board) on 11 May 1989 at Peyrat-le-Château and mechanically (using a mini-plug transplanting machine) on 10 May 1990 at Préchac. On the latter site, there was a serious problem with plug integrity, the plugs tending to break up during mechanical planting (R. Piesch, former manager of Arborgen-Europe, pers. comm.). This resulted in 1) many of the seedlings dropping out of the tray sideways, which caused mis-planting, and 2) a need for hand-replanting of mis-planted seedlings. This was carried out by manually pushing the plugs back down into the soil, which probably caused undue stress and root deformation. 


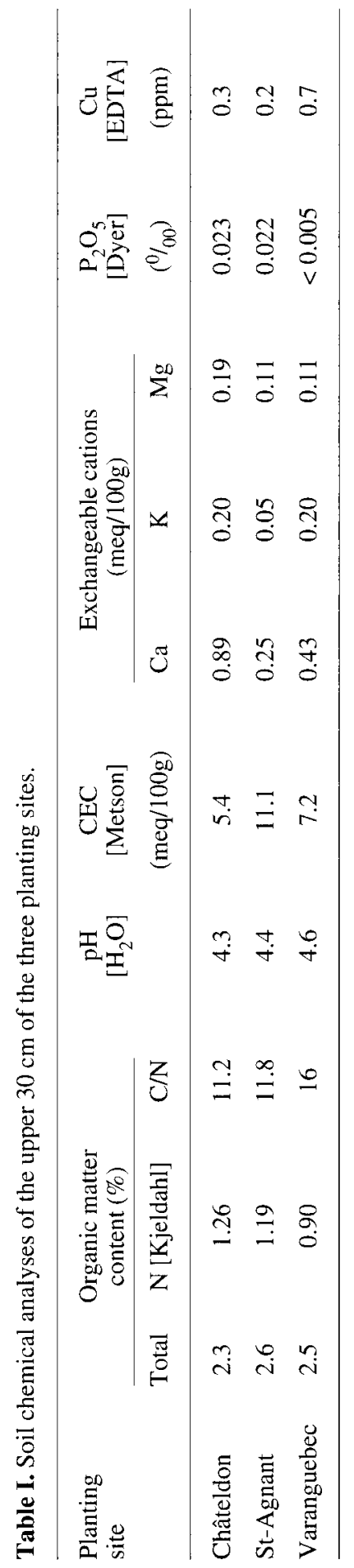




\subsubsection{Planting stock main features}

Initial height and stem diameter (measured at $5 \mathrm{~mm}$ above the soil surface) depended on seed sources, stock types and nursery conditions (table II). They were measured just after planting, so there was probably an additional effect of planting depth, which could partly account for the initial height differences in a given treatment between sites. Nevertheless, morphological variables such as height, stem diameter and height-todiameter ratio (sturdiness) varied mainly with stock types. On the one hand, MP +2 seedlings had large diameters, and were quite tall and sturdy. In contrast, MP +1 seedlings had small diameters, were short and very sturdy, but mean size values were quite high for this stock type [8]. In between, the $1+1$ and $2+1$ controls had intermediate diameters, and were generally rather tall. The $2+1$ seedlings planted at Varanguebec were by far the tallest.

All these stock types met the European morphological standards for Douglas fir seedlings. These standards do not include any specification in terms of quality of the root systems. Nevertheless, a quick survey of the planting material was made at the time of planting; it revealed frequent lateral root deformations (mainly $U$-shaped and twisted roots) on MPT seedlings, especially on the younger MP $+1 \mathrm{~s}$; these were probably mostly inherited from the mini-plug starter phase. Moreover, MP + 1 stock had only shallow roots tracing near the soil surface, and that was probably due to the transplanting problems.

\subsubsection{Lifting, handling and planting conditions}

The plants were lifted mechanically on 30 January 1991 at Préchac and on 19 March 1991 at Peyrat-le-Château. Just after lifting, the seedlings were quickly graded on the transplant beds, gathered into bundles, and placed in polythene-lined kraft paper bags which were sealed. The seedlings produced at Préchac were immediately shipped and set in cold storage $\left(2{ }^{\circ} \mathrm{C}\right)$ at the Naudet facility at Autun (Burgundy) until 18 March 1991. At this date, these seedlings were transported to Peyrat-le-Château where the four treatments were cold stored at $2{ }^{\circ} \mathrm{C}$ until the day before planting. During bed-run grading, the selection rate was similar for all stock types, with about $70 \%$ of the seedlings being considered good for planting.

On each planting site, traditional slit planting with a pickaxe was performed by tree planters who were local seasonal workers; site preparation and game protection, previous crop, planting date and spacing, are specified in table III.

\subsection{Field measurements and statistical analysis}

\subsection{Measurements}

All plants in the test were measured for height and stem diameter just after planting. Survival

Table II. Initial height $(\mathrm{cm})$, stem diameter at $5 \mathrm{~mm}$ above the ground $(\mathrm{mm})$ and height to diameter ratio $(\mathrm{mm} / \mathrm{mm})$ at planting.

\begin{tabular}{|c|c|c|c|c|c|}
\hline \multirow{2}{*}{$\begin{array}{l}\text { Planting } \\
\text { site }\end{array}$} & \multirow{2}{*}{$\begin{array}{c}\text { Initial } \\
\text { measurement }\end{array}$} & \multicolumn{4}{|c|}{ Douglas fir plant type } \\
\hline & & $2+1$ & $\mathrm{MP}+2$ & $1+1$ & $\mathrm{MP}+1$ \\
\hline Châteldon & $\begin{array}{c}\text { height } \\
\text { stem diameter } \\
\text { height / diameter }\end{array}$ & $\begin{array}{l}33.5 \mathrm{~B} \\
7.5 \mathrm{~B} \\
46 \mathrm{~B}\end{array}$ & $\begin{array}{c}44.5 \mathrm{~A} \\
10.1 \mathrm{~A} \\
44 \mathrm{~B}\end{array}$ & $\begin{array}{l}45.5 \mathrm{~A} \\
8.4 \mathrm{~B} \\
57 \mathrm{~A}\end{array}$ & $\begin{array}{l}22.5 \mathrm{C} \\
5.8 \mathrm{C} \\
39 \mathrm{C}\end{array}$ \\
\hline St-Agnant & $\begin{array}{c}\text { height } \\
\text { stem diameter } \\
\text { height / diameter }\end{array}$ & $\begin{array}{l}40.7 \mathrm{C} \\
8.1 \mathrm{~B} \\
51 \mathrm{~B}\end{array}$ & $\begin{array}{c}51.7 \mathrm{~A} \\
11.3 \mathrm{~A} \\
46 \mathrm{C}\end{array}$ & $\begin{array}{l}45.7 \mathrm{~B} \\
8.2 \mathrm{~B} \\
59 \mathrm{~A}\end{array}$ & $\begin{array}{l}27.8 \mathrm{D} \\
6.5 \mathrm{C} \\
43 \mathrm{D}\end{array}$ \\
\hline Varanguebec & $\begin{array}{c}\text { height } \\
\text { stem diameter } \\
\text { height / diameter }\end{array}$ & $\begin{array}{l}59.3 \mathrm{a} \\
8.8 \mathrm{~B} \\
69 \mathrm{~A}\end{array}$ & $\begin{array}{c}47.6 \mathrm{~b} \\
10.1 \mathrm{~A} \\
47 \mathrm{C}\end{array}$ & $\begin{array}{l}49.5 \mathrm{~b} \\
8.7 \mathrm{~B} \\
59 \mathrm{~B}\end{array}$ & $\begin{array}{l}25.3 \mathrm{c} \\
6.1 \mathrm{C} \\
43 \mathrm{D}\end{array}$ \\
\hline
\end{tabular}

On each line, values followed by all diflerent letters are significantly different at $P=5 \%$. The test used was Tukey's range test (after valid ANOVA) when small letters or Kruskal-Wallis non-parametric test (because of non-valid ANOVA) when capital letters. 
Table III. Conditions at planting on each field trial.

\begin{tabular}{lcccc}
\hline $\begin{array}{l}\text { Planting } \\
\text { site }\end{array}$ & $\begin{array}{c}\text { Planting } \\
\text { date }\end{array}$ & $\begin{array}{c}\text { Tree } \\
\text { spacing }\end{array}$ & $\begin{array}{c}\text { Previous } \\
\text { crop }\end{array}$ & $\begin{array}{c}\text { Site preparation, } \\
\text { game protection }\end{array}$ \\
\hline Châteldon & 27 March 1991 & $3 \times 3 \mathrm{~m}$ & $\begin{array}{c}\text { coppice of sessile } \\
\text { oak and hornbcam }\end{array}$ & $\begin{array}{c}\text { close-cropping } \\
\text { with a Rome blade, slash } \\
\text { put in swaths, subsoiling }\end{array}$ \\
\hline St-Agnant & 25 March 1991 & $3 \times 3 \mathrm{~m}$ & $\begin{array}{c}\text { heterogeneous stand } \\
\text { with juniper, Scots } \\
\text { pinc and birch }\end{array}$ & $\begin{array}{c}\text { subsoiling with a ripper, } \\
\text { remnants put in swaths }\end{array}$ \\
\hline Varanguebec & 4 April 1991 & $3.5 \times 3 \mathrm{~m}$ & $\begin{array}{c}\text { coppice with standards } \\
\text { dominated by } \\
\text { pedunculate oak }\end{array}$ & $\begin{array}{c}\text { Subsoiling, enclosure } \\
\text { fence (deer) } \\
\text { plus individual plastic } \\
\text { fences (rabbit) }\end{array}$ \\
\hline
\end{tabular}

and height were observed each subsequent year during the first three growing seasons. At age 5, a complete assessment was made of survival, height and diameter at $1 \mathrm{~m}$ above ground line. At Varanguebec, an additional final measurement was made on wind-stability because of wind-throw damage in January 1995 due to exceptional monthly rainfall $(260 \mathrm{~mm}$, mostly between 17 and 29 January) and high-wind events ( 25 days with gusts over $60 \mathrm{~km} / \mathrm{h}$, the maximum being $135 \mathrm{~km} / \mathrm{h}$ on the $20 \mathrm{th}$ ). After the storm, bent trees were set upright and earthed up. On each site, and for each measurement, game and clearing damage were also recorded to exclude such plants from the analysis on dimensions.

\subsubsection{Statistical analyses}

The statistical analyses were made with 'Statgraphics Plus' for Windows software version 1, on individual values as in the following.

a) On mortality and damage rates, Chi-square test was used first on all treatments. In case of significant difference at the $5 \%$ level, the treatments were compared two by two to rank them. Moreover, the ranking of trcatments was checked on each block in order to detect possible interactions between blocks and treatments.

b) Height, diameter and growth were analysed using analysis of variance (ANOVA). Its use supposes the lay-out to be orthogonal (all treatments have living and healthy plants in all blocks) and each variable must meet the three following assumptions: normally distributed data, homogeneous and independent treatment residuals.

If these assumptions were met on treatments and on blocks, a two-way ANOVA was performed using the interactive model. Sometimes, data transformations were required. To rank treatments, the interaction between blocks and treatments had to be either insignificant at the $5 \%$ level or negligible compared to the treatment effect. This condition was always verified. After valid ANOVA, all mean separations were performed using Tukey's range test, at a $5 \%$ level.

When at least one of the assumptions was not met, the non-parametric Kruskal-Wallis test was used. Based upon rank analysis among treatments, it is less precise than ANOVA because block-treatment interactions are not taken into account. Nevertheless, when significant differences were detected at a $5 \%$ level, treatments were compared by pairs (Mann-Whitney test) for ranking.

\section{RESULTS}

\subsection{Survival rate}

Five years after planting, survival was very high on all sites and for all treatments (table $I V$ ). Nevertheless, a slight but significant decrease in survival occurred with 
Table IV. Height $(\mathrm{cm})$, diameter at $1 \mathrm{~m}$ above the ground line $(\mathrm{cm})$ followed by the number of measurable trees in brackets, and survival (\%) of the tested saplings 5 years after planting.

\begin{tabular}{|c|c|c|c|c|c|}
\hline \multirow{2}{*}{$\begin{array}{l}\text { Planting } \\
\text { site }\end{array}$} & \multirow{2}{*}{$\begin{array}{c}\text { Measurement } \\
\text { at age } 5\end{array}$} & \multicolumn{4}{|c|}{ Douglas fir plant type } \\
\hline & & $2+1$ & $\mathrm{MP}+2$ & $1+1$ & $\mathrm{MP}+1$ \\
\hline Châteldon & $\begin{array}{l}\text { height } \\
\text { 1-m-high diameter } \\
\text { survival rate }\end{array}$ & $\begin{array}{c}363 \mathrm{~b} \\
4.3 \mathrm{~A}(156) \\
96 \mathrm{a}\end{array}$ & $\begin{array}{c}387 \mathrm{a} \\
3.9 \mathrm{~B}(153) \\
97 \mathrm{a}\end{array}$ & $\begin{array}{c}378 \mathrm{ab} \\
4.3 \mathrm{~A}(145) \\
90 \mathrm{~b}\end{array}$ & $\begin{array}{c}340 \mathrm{c} \\
3.6 \mathrm{C}(153) \\
96 \mathrm{a}\end{array}$ \\
\hline St-Agnant & $\begin{array}{c}\text { height } \\
\text { 1-m-high diameter } \\
\text { survival rate }\end{array}$ & $\begin{array}{c}142 \mathrm{~b} \\
1.8 \mathrm{~b}(74) \\
95 \mathrm{~b}\end{array}$ & $\begin{array}{c}233 \mathrm{a} \\
2.9 \mathrm{a}(142) \\
99 \mathrm{a}\end{array}$ & $\begin{array}{c}155 \mathrm{~b} \\
2.1 \mathrm{~b}(81) \\
93 \mathrm{~b}\end{array}$ & $\begin{array}{c}84 \mathrm{c} \\
1.6 \mathrm{~b}(23) \\
96 \mathrm{ab}\end{array}$ \\
\hline Varanguebec & $\begin{array}{c}\text { height } \\
\text { 1-m-high diameter } \\
\text { survival rate }\end{array}$ & $\begin{array}{c}216 \mathrm{c} \\
2.7 \mathrm{~b}(148) \\
98 \mathrm{a}\end{array}$ & $\begin{array}{c}297 \mathrm{a} \\
3.8 \mathrm{a}(149) \\
97 \mathrm{a}\end{array}$ & $\begin{array}{c}235 \mathrm{~b} \\
2.1 \mathrm{c}(145) \\
98 \mathrm{a}\end{array}$ & $\begin{array}{c}206 \mathrm{c} \\
1.6 \mathrm{~d}(129) \\
94 \mathrm{a}\end{array}$ \\
\hline
\end{tabular}

On each line, values followed by all different letters are significantly different at $P=5 \%$. For height and diameter, the test used was Tukey's range test (after valid ANOVA) when small letters or Kruskal-Wallis nonparametric test (because of non-valid ANOVA) when capital letters. In parentheses, the number of trees measured for diameter is specified. On survival, Chi-square test was used.

$1+1$ stock compared to all other treatments at Châteldon, and on $2+1$ and $1+1$ controls versus $\mathrm{MP}+2$ stock at St-Agnant. With $1+$ 1 stock, these differences in survival appeared as early as the planting year, and may have been associated with transplanting shock. With the $2+1$ stock, a significant difference appeared between the third and the fifth year after planting, and was unexplained.

\subsection{Five-year height}

The highest values were obtained at Châteldon and the lowest at St-Agnant, Varanguebec being intermediate. The differences among treatments were large. Saplings grown in the same nursery were compared first. On the one hand, $\mathrm{MP}+1$ stock was significantly smaller than its $1+1$ control while, on the other hand, MP +2 stock was larger than its $2+1$ control. These observations apply to all three planting sites, but differences between treatments decrease in both absolute and relative values with mean height (i.e. with soil fertility). As a result, if we compare the extreme mean values at age 5, MP +1 height represents only $36 \%$ of $\mathrm{MP}+2$ height at St-Agnant, but $94 \%$ at Châteldon.

Regarding the $1+1$ and $2+1$ standards, their mean height values were similar at Châteldon and St-Agnant, when the same seed source was used (EMC), and differed slightly at Varanguebec, where seed sources were different.

An additional investigation was made on the possible relationships between final height and initial dimensions (i.e. height, stem diameter and sturdiness), on individual values for each site. Regression coefficients (r) from the best predictive models were lower than 0.60 , in all cases, and overall variance was always mostly due to differences between treatments.

\subsection{Cumulative 5-year height growth}

The results are presented in figure 2. Across sites, they coincide with 5-year height: growth was better at Châteldon and poorer at St-Agnant, Varanguebec being in 


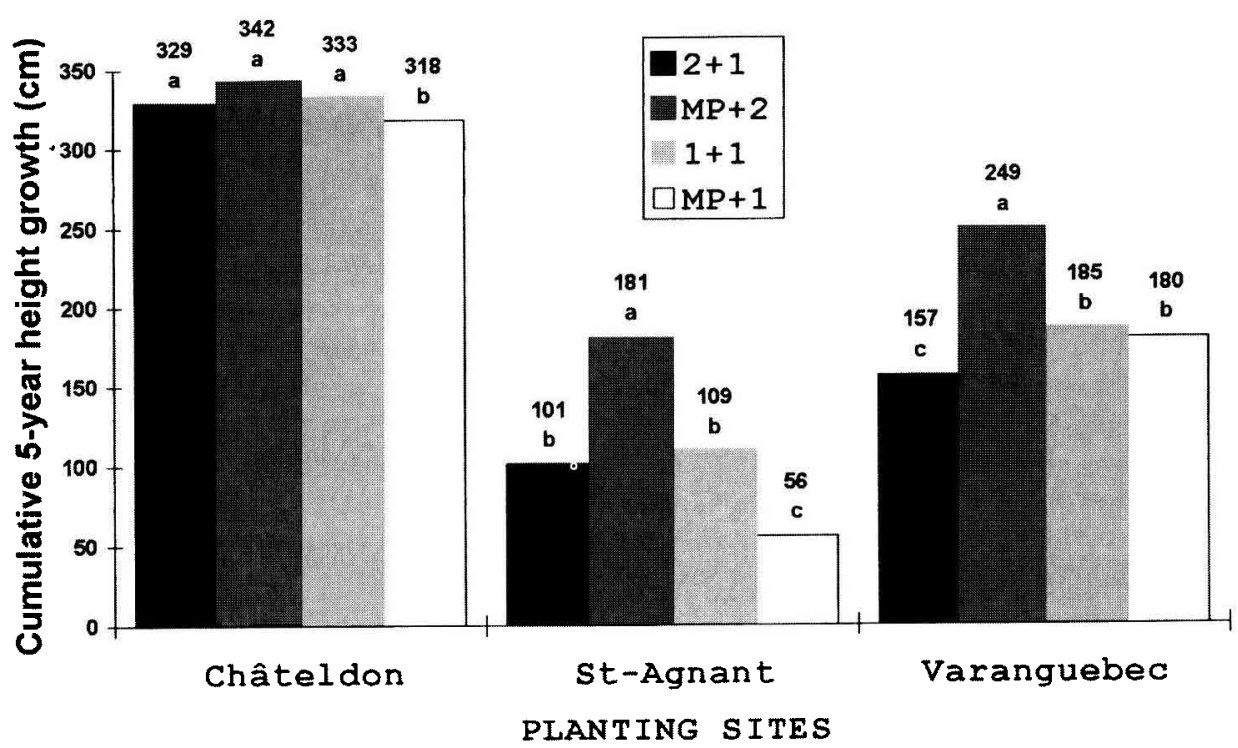

Figure 2. Cumulative 5-year height growth of the tested stock types on each planting site.

between. Among treatments, two statistical differences in height disappeared for growth because mean heights differed at planting. Thus, for 5-year growth, MP +2 equalled $2+1$ at Châteldon and $\mathrm{MP}+1$ equalled $1+$ 1 at Varanguebec. All other results were similar to those for 5-year height.

\subsection{Height growth kinetics}

Growth kinetics depended on sites and treatments (figure 3). Planting sites mainly influenced the form of the growing curve whereas the range of values varied each year with treatments.

Across sites, at Châteldon, the growth rate increased during the first 3 years after planting, reached a peak at age 3 , and decreased slightly during the next two growing seasons. At Varanguebec, the results were similar, but 2 nd-year and 3rd-year growth rates were very similar. At StAgnant, the annual growth rate kept increasing during the first five growing seasons, so that the final values were close to those of Varanguebec.

Among treatments, growth kinetics varied with site.

At Châteldon, 1st-year growth was greater by $7 \mathrm{~cm}$ for seedlings grown at Préchac $(1+1$ and $M P+1)$. This trend disappeared completely in the following years. Thus, at ages 2 and 3, the annual growth was greater on MP +2 versus all other treatments. At age 3, the MP + 1 stock had significantly slower growth. During the 4th and 5 th years, MP +1 had a slower growth than only the $2+1$.

At St-Agnant, only MP +2 had the best growth every year, except in the first year when it shared this rank with $\mathbf{1}+1$. Conversely, only MP +1 stock had the lowest performance every year. In between, $1+1$ performed better than $2+1$ during the first 2 years, and equally, afterwards.

At Varanguebec, on seedlings reared at Peyrat-le-Château, MP +2 stock grew better than the $2+1$ control every year. On 

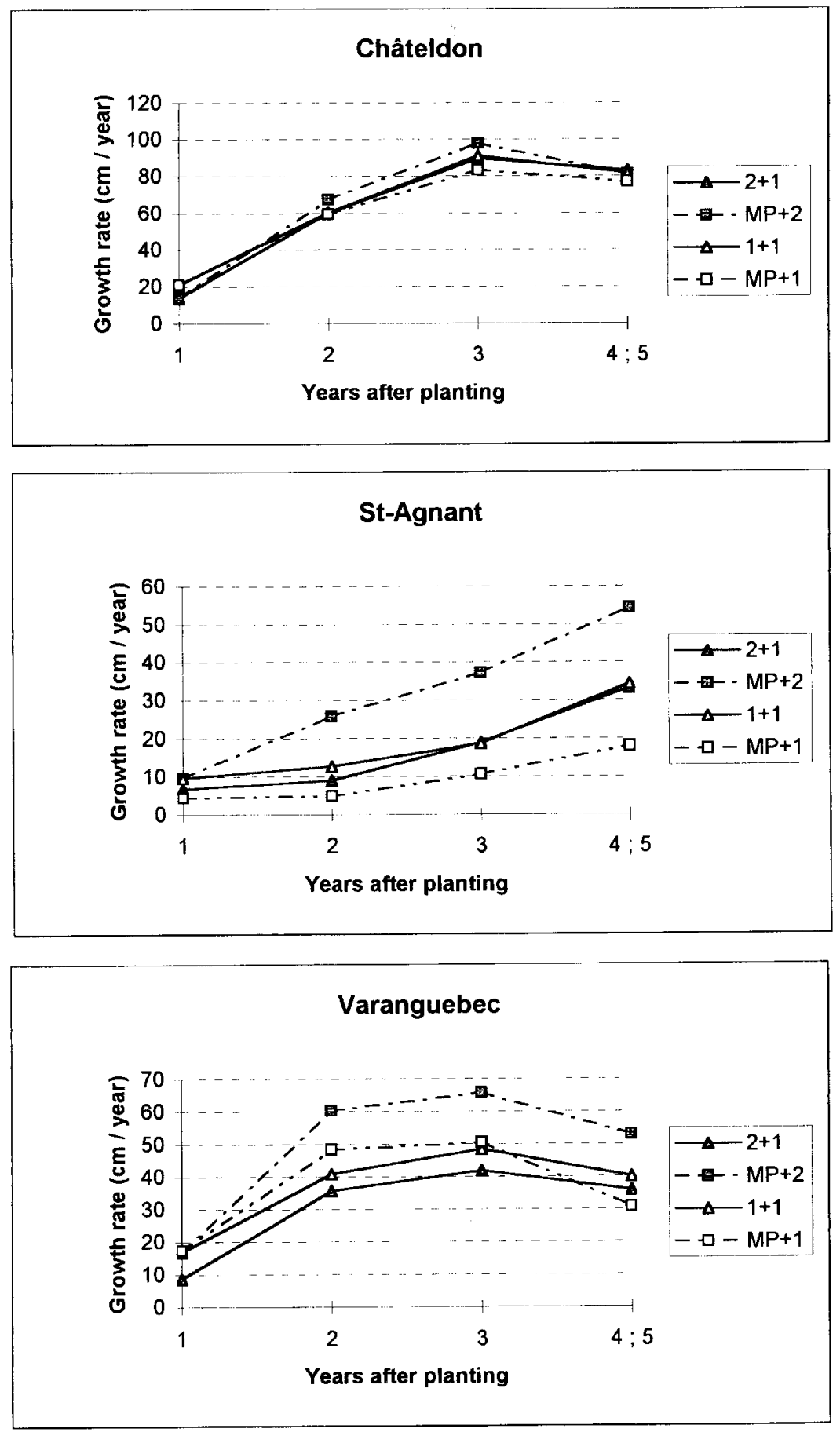

Figure 3. Time-courses of yearly height growth of the tested stock types on each planting site. 
seedlings coming from Préchac, $\mathrm{MP}+1$ annual growth was statistically the same as that of its $1+1$ control at age 1 and age 3 , but it was better at age 2 and slower at age 4-5.

Moreover, the growth curves of the two controls $(1+1$ and $2+1)$ were very similar, $1+1$ being slightly greater than $2+1$ with an early significant difference which disappeared at age 4-5.

\subsubsection{Stem diameter at $1 \mathrm{~m}$ above ground line at age 5}

This measurement was taken only on trees which were over $1.2 \mathrm{~m}$ high, whose numbers varied considerably with site and treatment. The results are shown in table IV. To eliminate sample-size bias when comparing mean stock diameters, similar numbers of measured trees were needed. At Châteldon and Varanguebec, most of the trees were measured, but not at St-Agnant.

At Châteldon, the diameter was greater on controls than on MPT, irrespective of the nursery site; the result was not linked to height differences but to sapling sturdiness. Moreover, MP +1 mean diameter was lower than for $\mathrm{MP}+2$, but the difference was mainly due to a shorter height.

At St-Agnant, the results showed that the two controls $(2+1$ and $1+1)$ performed the same in diameter as in height. With MPT, mean diameter was influenced by the number of measured trees and by their mean height, which were both very different between the two stock types and also versus controls.

At Varanguebec, all treatments differed significantly. Their ranking was the same as for height, but $\mathrm{MP}+1$ behaved the poorest, probably because of increased windthrow damage.

\subsubsection{Wind-throw and root deformity analyses at Varanguebec}

High rainfall and high winds accounted in part for wind-throw at Varanguebec, in the fifth year after planting. Nevertheless, proportion of wind-blown trees depended on treatments: $23 \%$ on $\mathrm{MP}+1,20 \%$ on $2+1$, $13 \%$ on $1+1$ and $5 \%$ on $\mathrm{MP}+2$. A Chisquare test showed that meaningful differences appeared first between MP +2 which was relatively wind-resistant, and all other treatments, and second, between $1+1$ (intermediate behaviour) and MP +1 which was severely damaged. The sensitivity to blowdown damage differed with treatments and could have been associated with root deformation.

A sample of ten representative saplings per treatment was excavated on 15 November 1995 from an additional plot established for destructive analyses. The root deformities of these trees were assessed. The results revealed that the roots present at planting had often been compressed into a flat plane. In addition, the taproot of numerous seedlings appeared to have been bent ( $\mathrm{J}$ rooted), especially for $2+1$ s which were longer, at the time of planting. At age 5, only MP +2 seedlings were well-anchored because they had developed a symmetrical array of sturdy roots. By contrast, $\mathrm{MP}+1$ stock very often revealed a poor and shallow root system, with also some spiralled or kinked roots.

\section{DISCUSSION}

The two types of MPT tested in the three forest sites performed very differently across the sites, between themselves and also compared to their own control groups, which originated from the same seed source and which were grown in the same nursery.

The MP +2 stock produced at Peyrat-leChâteau showed promise: on low and medium-fertility soils (St-Agnant and Varanguebec, respectively), it survived very well, had by far the highest 5-year cumulative growth and 5-year height among treatments, and consequently the best diameter at $1 \mathrm{~m}$ above ground line at age 5 . On a highfertility soil (Châteldon), its 5-year cumu- 
lative growth improved but did not differ from that of two other treatments $(2+1$ and $1+1)$; its diameter at $1 \mathrm{~m}$ above the ground at age 5 was even slightly less than that of its $2+1$ control, but survival was unaffected. Thus, even if these MP +2 saplings were more slender on the latter site, their future is promising, because 5 years after planting the root system was probably well-anchored as at Varanguebec. To conclude on $\mathrm{MP}+2$, its use seems appropriate on all sites; furthermore, the poorer the soil, the higher the gain over control.

The MP +1 stock grown at the nursery of Préchac was disappointing. Its performance was generally low on all planting sites compared to its $1+1$ control. At St-Agnant, on a low-fertility soil, the growth of the MP + 1 stock since planting has been so poor that it leads us to question their suitability for reforestation purposes. At Varanguebec and Châteldon, on medium- and high-fertility soils, respectively, a slight but significant decrease in 5-year height and diameter at $1 \mathrm{~m}$ above ground line was observed. Cumulative height growth was also affected at Châteldon, from the third year after planting but not at Varanguebec. On the latter site, the MP +1 height growth was even enhanced at age 2 but, during years 4-5, the wind-throw damage which was more acute on this treatment, led to a levelling off of growth performance. Root deformities were shown to be an additional problem on $\mathrm{MP}+1$, which could be partly inherited from the transplanting problems. The only meaningful advantage of $\mathrm{MP}+1$ over its $1+1$ control was to increase survival by $6 \%$ at Châteldon, but this is not of practical importance to foresters. Nevertheless, this slight gain in survival might be linked to a better water stress tolerance during planting shock [13]. To conclude with MP +1 seedlings, we must emphasize that they were the smallest at planting, even if larger than usual for this stock type [8], and they did not fully meet the French morphological standards (minimum height: $25 \mathrm{~cm}$ ), even if their sturdiness was adequate. This smaller size should not have depressed cumulated growth [15], even on a skeletal soil [9]; the absence of correlation between initial seedling sizes (height, diameter and height to diameter ratio) and final height was checked on each field trial.

Both controls, $2+1$ and $1+1$, behaved similarly at age 5, at Châteldon and StAgnant where they originated from the same seed source. A slight but significant difference was observed at Varenguebec, probably because the two stock types were of different provenances. There was no evidence of a nursery site effect on performance 5 years after planting, so that the only known effect was on the duration of the growing period ( 2 years at Préchac versus 3 years at Peyrat-le-Château).

In the absence of proven nursery site effects on controls, the high performance of $\mathrm{MP}+2$ stock as compared to the poor behaviour of MP +1 stock was a surprise which needs to be explained. Poor plug integrity during mechanical transplanting at Préchac resulted in most seedlings having to be re-planted by hand. This probably caused increased root deformities and lack of anchor roots, still visible 5 years after planting, at Varanguebec. The same reason could explain the poor field performance of $\mathrm{MP}+1$ stock 5 years after planting, especially on nutrient-depressed soils. The fact that the MP + 2 stock did exceptionally well in the field suggests that the MPT concept is viable if the stock is transplanted and grown properly in the nursery.

On a commercial scale, production costs of MPT stocks are relatively low [15], MP + 1s being currently similar to those of $1+1$ stock, and $\mathrm{MP}+2 \mathrm{~s}$ being probably similar to those of $2+1$ stock. Keeping costs low implies a high degree of mechanization and success in the operations, especially for transplanting, which was not experienced in this study. 


\section{ACKNOWLEDGEMENTS}

The author wishes to thank Jean-Michel Amirault, from Cemagref, for his technical assistance, Richard Piesch, Barbara and David Thompson, former managers of ArborgenEurope, for their large contribution on producing MPT, for their support for field establishment, and for their comments on the manuscript. Thanks also to the Naudet Company, to the State forest nursery at Peyrat-le-Château and to the private land owners and foresters associated with the study.

\section{REFERENCES}

[1] Amott J.T., Pendl F.T., Field performance of several tree species and stock types planted in montane forests of coastal British Columbia, Information Rep., Can. For. Serv., no. BC-X-347, 1994, 45 p.

[2] Bonneau M., Causes de la déformation des jeunes Douglas dans le Limousin, Ann. Sci. For. 28 (1971) 341-353.

[3] Cemagref, Results of Plug Trials 1989, Tech. Rep., Cemagref, Nogent-sur-Vernisson, 1993, $12 \mathrm{p}$. $416 \mathrm{p}$.

[4] de Champs J., Le Douglas, Afocel, Paris, 1997,

[5] Gilbert J.M., Stations forestières et production du Douglas dans le pays d'Othe, Rev. For. Fr. 47 (1995) 343-356.

[6] Gonda H., Mondino V., Production of accelerated transplants of Ponderosa pine and Douglas fir in the Patagonian Andes, in: OFRI (Eds.), Abstracts of 'Making the Grade', Int. Symp., 11-15 September 1994, Sault-Ste-Marie, Ontario, Canada, 1994, p. 51.

[7] Hahn P.F., Plug + 1 seedling production, in: Duryea M.L., Landis T.D. (Eds.), Forest Nursery Man- ual: Production of Bareroot Seedlings, M. Nijhoff/Dr W. Junk Publ., The Hague, 1984, pp. 165-181.

[8] Hee S.M., Stevens T.S., Walch D.C., Production aspects of mini-plug transplants, in: Proc. Combined Meeting of the Western Forest Nursery Assoc., 8-11 August 1988, Vernon, British Columbia, Canada, Gen. Tech. Rep. RM-167, USDA For. Serv., 1990, pp. 168-171.

[9] Hobbs S.D., Crawford M.S., Yelczyn B.A., Early development of three Douglas fir stock types on a droughty skeletal soil, West. J. Appl. For. 4 (1989) 21-24.

[10] Jamagne M., Bases et techniques d'une cartographie des sols, Ann. Agro. 18 (hors-série) (1967) $142 \mathrm{p}$.

[11] Mc Creary D., Lippitt L., Producing blue oak seedlings: comparing mini-plug transplants to standard bareroot and container stock, in: Gen. Tech. Rep. PNW-GTR-389, USDA For. Serv., 1997, pp. 253-254.

[12] Ritchie G.A., Tanaka Y., Duke S.D., Physiology and morphology of Douglas fir rooted cuttings compared to seedlings and transplants, Tree Physiol. 10 (1992) 179-194.

[13] Rose R., Gleason J.F., Atkinson M., Morphological and water-stress characteristics of three Douglas fir stocktypes in relation to seedling performance under different soil moisture conditions, New For. 7 (1993) $1-17$.

[14] Schalla S.L., Doughton K., Transplanting the Douglas fir plug, in: Combined Proc. International Plant Propagators' Society, USA, vol. 28, 1978, pp. 177-184

[15] Tanaka Y., Carrier B., Dobkowski A., Figueroa P., Meade R., Field performance of miniplug transplants, in: Proc. Combined Meeting of the Western Forest Nursery Assoc., 8-11 August 1988, Vernon, British Columbia, Canada, Gen. Tech. Rep. RM-167, USDA For. Serv., 1990, pp. 172-181.

[16] Tinus R.W., A Trial of Plug Transplant Seedling Production in the Southwest, West. J. Appl. For. 11 (1996) 81-84. 